\title{
Histological study of sheep skin transformation during the recreation of historical parchment manufacture
}

\author{
Marc Fourneau 1*, Caroline Canon², Daniel Van Vlaender ${ }^{2}$, Matthew J. Collins ${ }^{3,4}$, Sarah Fiddyment ${ }^{3}$, \\ Yves Poumay ${ }^{2}$ and Olivier Deparis ${ }^{5}$ D
}

\begin{abstract}
We report a simple histological study on skin biopsies from young domestic sheep following each step in transformation from skin to parchment production. During the recreation of historical parchment manufacture, histological analyses were conducted; before and after lime treatment, hair removal, and stretching. Sections were fixed and stained using a variety of histological stains to identify the presence of different molecular classes and the fibrous proteins, collagen and elastin. The results reveal surprisingly few histological changes in most steps in the production process. However, very visible changes in the supramolecular ordering of skin macromolecules (elastin, collagen) occur during the final stage of parchment production when stretched on the frame. Collagen fibres and hair follicles were all strongly re-oriented in the direction of strain. Surprisingly despite the thinness of the lambskin and the exhaustive treatment in lime, not all fats were saponified and even in the final product Oil Red O stained fat bodies were detectable on the hair side of the skin. We believe this study will help compensate for the lack of sources on microscopic changes in parchment during the recreation of its historical manufacture.
\end{abstract}

Keywords: Sheep skin, Histology, Parchment, Collagen, Elastin, Lipid

\section{Introduction}

Studies on the histology of animal skins have mainly focused on living animals, exploring pathology [1, 2], differences between species $[3,4]$ or breeds $[5,6]$, structural features $[5,7]$ or specific constituents $[1,8]$. Some are focused on hair follicles and parchment grain surfaces in leather $[2,3,6,9,10]$ or parchments $[10-12]$, both in terms of species differences and quality. However, the transformation of the skin, from rawhide to parchment, has rarely been reported, a notable exception being the work of Saxl [13, 14].

Recent research [15] has revealed that sheep skins have been widely employed for parchment production throughout history, typically for legal documents. In this

*Correspondence: marc.fourneau@gsk.com

${ }^{1}$ GSK Vaccines, Rue de I'Institut 89, 1330 Rixensart, Belgium

Full list of author information is available at the end of the article paper we explore the histological changes that occur to fresh sheep skins during the different stages employed in parchment production. Using an old manufacturing recipe [16], and by studying the impact of changes in the ingredients and processes we hope to better interpret the results of previous studies of old manuscripts.

There have been few previous histological studies of parchment [e.g. 13, 17-19] and none have followed the process of parchment manufacture. By documenting how each stage is processed and by taking successive samples it will be possible to correlate with the non-invasive procedures currently used to decipher the production of parchment (SEM, XRF, Raman, etc.) from unknown historic production methods. The resulting data from experimental manufacture can then be compared with non-invasive methods applied to historical material [15, $20,21]$, as it was in a recent article [22] in which the

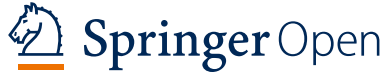

(c) The Author(s) 2020. This article is licensed under a Creative Commons Attribution 4.0 International License, which permits use, sharing. adaptation, distribution and reproduction in any medium or format, as long as you give appropriate credit to the original author(s) and the source, provide a link to the Creative Commons licence, and indicate if changes were made. The images or other third party material in this article are included in the article's Creative Commons licence, unless indicated otherwise in a credit line to the material. If material is not included in the article's Creative Commons licence and your intended use is not permitted by statutory regulation or exceeds the permitted use, you will need to obtain permission directly from the copyright holder. To view a copy of this licence, visit http://creativeco mmons.org/licenses/by/4.0/. The Creative Commons Public Domain Dedication waiver (http://creativecommons.org/publicdomain/ zero/1.0/) applies to the data made available in this article, unless otherwise stated in a credit line to the data. 
authors conclude that "the skin studied was first tawed with alum and then dressed with gypsum".

\section{Skin structure}

Sheepskin, like the skin of other mammals, is divided into two layers: the (outer) epidermis and the (inner) dermis (Fig. 1). The epidermis is an epithelial tissue made mainly by cohesive cells called keratinocytes. The differentiation of these cells generates four classical layers in the epidermis: stratum basale, stratum spinosum, stratum granulosum and stratum corneum.

The sublining dermis is a connective tissue rich in collagen fibers. Invaginations of the epidermis form hair follicles in the dermis, with their attached sebaceous glands, containing sebocytes rich in lipids. Smooth muscle cells from the hair erector muscle attach the hair follicle to the epidermis.

The greasiness that is noted in the processing of sheep skins stems from the distinct distribution of fat specific to sheep because of the abundance of secondary follicles in fine wooled sheep, to which are attached sebaceous glands [23]. The lipids produced and secreted by these glands (notably lanolin) generate a lipid layer below the epidermis separate from the usual subcutaneous fat. The greater the number of follicles, the more lipids that will be produced. It is this additional lipid layer that contributes to the 'delaminating' effect observed in sheep parchment [24-26], where the skin can be effectively split into two thinner layers.

\section{Materials and methods}

\section{Parchment preparation}

The skins from four lambs (Ovis aries) were taken from the Ovine Center of the University of Namur (natural deaths); the animals were cared for according to procedures conforming to the European requirements on farm animals (EC directive 86/609). The skins-two stillborn animals and two from animals less than 2 weeks old (approximately a rectangular shape and size of $16 \mathrm{~cm}$ by $20 \mathrm{~cm}$ or lower) were manufactured into parchment. Recipes for parchment production exist from the 8thC [14], the first well documented example being John Beale in "The Art of making Parchment, Vellum, Glue etc." read to the Royal Society in 1664 [27]. Here we used the later description of Diderot \& D'Alembert [16].

\section{Preparation}

Fresh skins were washed in water then left in a light lime solution $(3 \mathrm{~g} / \mathrm{l})$ for 5 days.

\section{Dehairing}

Two dehairing processes were used (each treatment was applied on one born dead animal and one animal less than 2 weeks old), both at ambient temperature, either:

1. The flesh side of a skin was uniformly covered with a milky lime solution and left for 1 week folded in two, flesh side together (pancake method).

2. The full skin was put into a lime bath and left for 1 week (bath method).

Skins were dehaired using successively stronger lime $\mathrm{Ca}(\mathrm{OH})_{2}$ solutions $\left(5 \mathrm{~g} \mathrm{Ca}(\mathrm{OH})_{2} / \mathrm{l}, 15 \mathrm{~g} / \mathrm{l}\right.$ and $\left.30 \mathrm{~g} / \mathrm{l}\right)$, equivalent to 'plein mort', 'plein gris' and 'plein vif' for 1 week each, with a wash in clean water for 1 day in between each different solution.

\section{Scraping}

The hair was removed by rubbing the skin with hands and finished with a semi lunar knife. The skins were then put on a framed, scraped, chalked and pounced, to produce the final parchment.

\section{Box 1}

Aussi-tôt que les peaux ont été pelées, on les lave à la rivière afin de les nettoyer, on les laisse ensuite égoutter quelque temps; après quoi on les met dans un

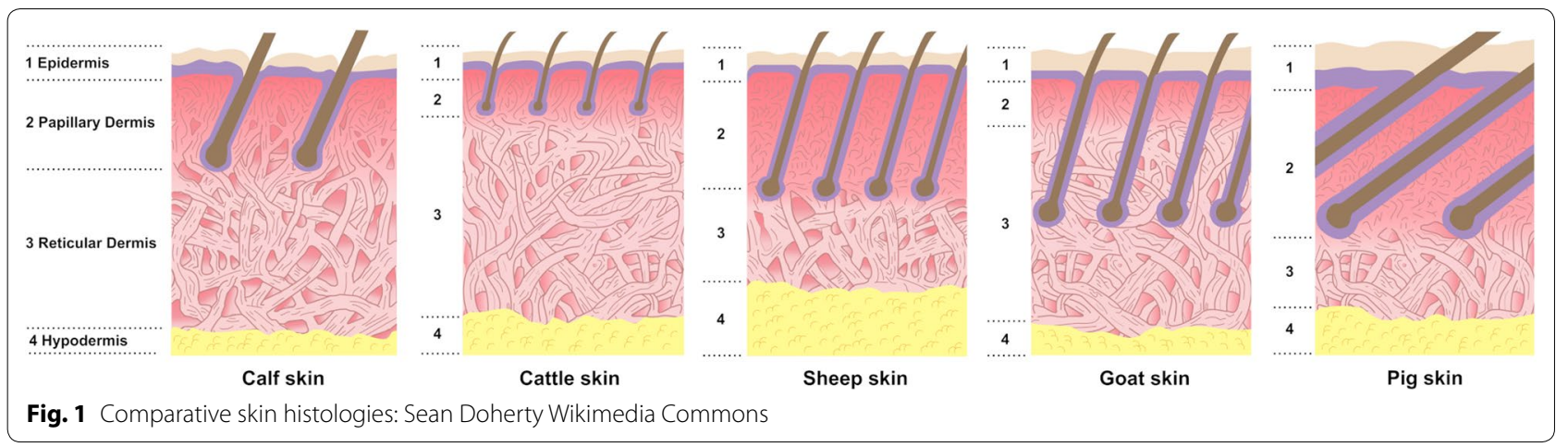


mort-plein, c'est-à-dire dans un plein qui a servi et dont la chaux a presque perdu toute sa force;

on les laisse dans ce mort-plein environ vingt-quatre heures;

d'où on les retire ensuite pour les mettre égoutter sur le plein....

Deux jours après que les peaux sont sorties du mortplein, on les plonge dans un autre plein dont la chaux est moins usée, on les y laisse environ deux ou trois jours, après lesquels on les retire pour les mettre en retraite égoutter comme auparavant....

s'il en est besoin, on les replonge ensuite dans le plein, on réitère cette opération pendant six semaines ou deux mois seulement, pendant les chaleurs de lété; mais en hiver il faut les faire passer successivement de plein en plein au-moins pendant trois mois.

Diderot \& D'Alembert (1765).

Once the skins are peeled, they are washed in the river, then allowed to drain for some time; next they are put into 'dead-lime' that is to say, lime which has lost almost all its strength.

Skins are left in baths of dead-lime for about $24 \mathrm{~h}$;

They are removed and allowed to fully drain again.

Two days after the skins are removed from the deadlime, they are immersed in another bath with less aged lime and left there for about 2 or 3 days with agitation, after which they are removed put to drain....

If necessary, they are then plunged back in the lime bath again, this operation is repeated for between 6 weeks to 2 months during the heat of summer, but in winter in the open it is necessary for the skins to soak for at-least 3 months.

loose translation, Matthew Collins.

Two subsamples of skins were taken at each step of the manufacturing processes described by Diderot and D'Alembert [16] and placed immediately in formaldehyde for subsequent histological analyses: one for the paraffin embedding and the other one for the frozen section to enable alternative histochemical staining to be used. Samples of approximately one square centimeter were taken in periphery of the skin, after specific steps of the manufacturing process: fresh skin (sample $\# 1$ ), skin after hair removal (sample \#2), skin after the 3rd lime bath (sample \#3), parchment (sample \#4).

Method: Histological procedures:

The sheepskin and parchment samples were fixed in acetified formalin (formol $4 \%$, acetic acid 1\%). Six micron thick sections of the paraffin and of the frozen blocks were placed on SuperFrost + glass slides.

Sections from the paraffin blocks were dewaxed, rehydrated in graded alcohols and stained using the five following methods, (the two first being generalized topographic stains, while the three others are specific for specific macromolecules):

(1) Hemalun, Erythrosin and Saffron (HES) stains nucleic acid blue/purple, cytoplasmic proteins red and collagen yellow-orange.

(2) Green trichrome stains nucleic acid in blue/purple, cytoplasmic proteins red and collagen green;

(3) Orcein and hematoxylin stains elastin fibers red brown and nuclei in blue/purple.

(4) Picro-Sirius Red and hematoxylin stains collagen I fibers and nuclei in blue/purple.

(5) Wilder and green light stains reticulin fibers, mainly collagen III fiber black with a green background.

Sections from the frozen blocks were stained with Oil Red $O(O R O)$ and hematoxylin which stains lipids red and nuclei blue.

\section{Results and discussion}

From a histological point of view, samples taken from the four skins shared similar changes during parchment production, there were no significant differences between stillborn and two-weeks old animals. Nor did the two different dehairing processes (i.e. pancake method versus bath method) result in any histological differences in the appearance of tissues (Fig. 2).

\section{Pre-treated skins}

Histological sections of the pre-treated skin (samples \#1; Fig. 3) exhibited typical histological features, expected from fresh skin. The density of the hairs is highest in the grain layer, where they occupy at least half the total thickness of the skin. We did not observe any histological structure related to the subcutaneous tissue. This may be due to us sampling at the periphery of the skin (given the unevenly distributed layer thickness over the body), the (young) age of the animal and/or the way the skin was removed.

Orcein staining shows that the elastin fibers are preferentially located in the deep dermis, close to the (missing) subcutaneous layer and are more abundant around hair follicles. Picrosirius stain highlights the ubiquitous presence of collagen everywhere in the dermis in abundant bundles. The Wilder stain shows presence of reticulin fibers underlining the basement membranes, and perhaps some sparse fibers in the dermis. The specific staining of ORO reveals the presence of fats in the sebocytes of the sebaceous glands confirming previous observations by Haines [12]. Fats are present discreetly in the stratum granulosum and rarely in the stratum corneum. 


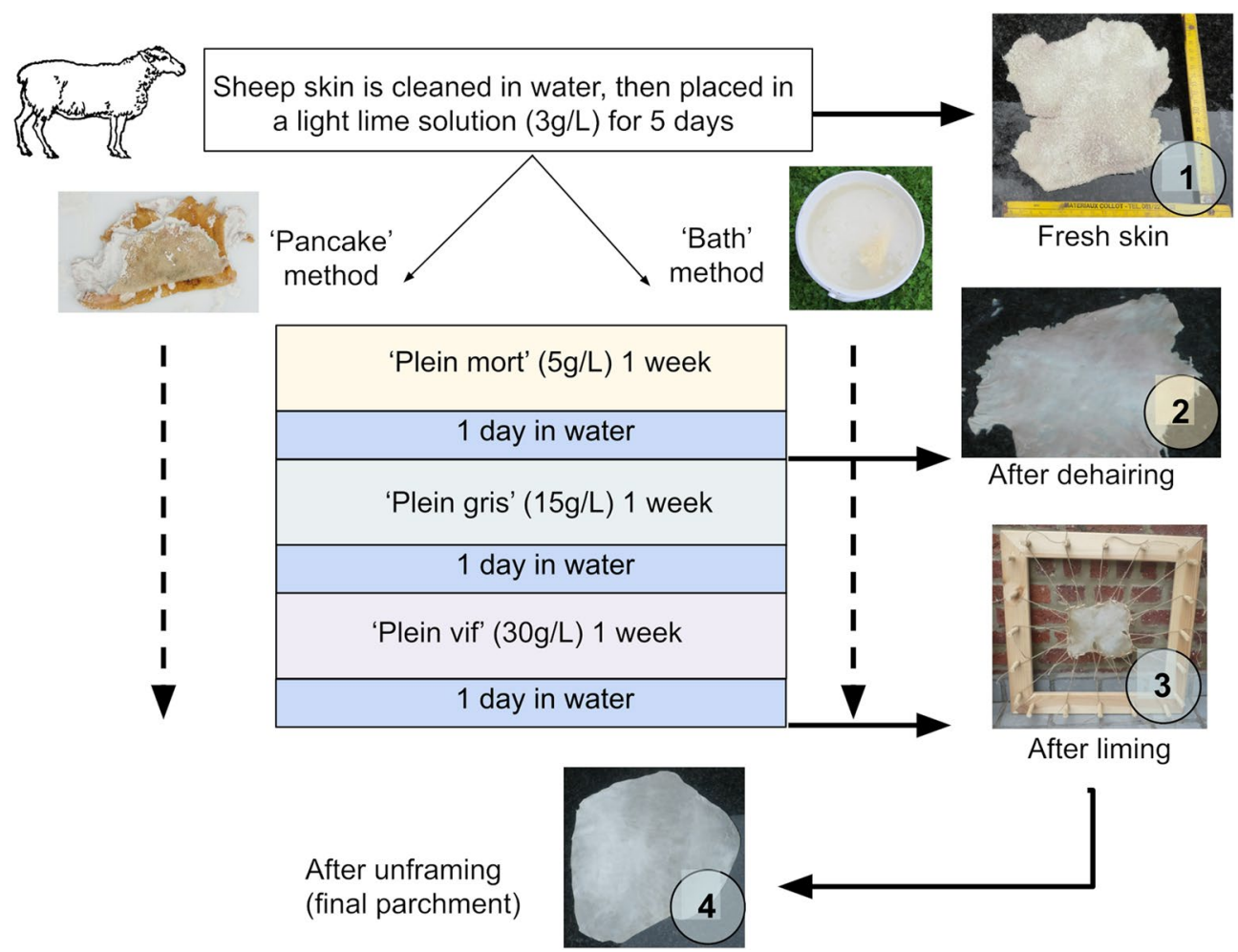

Fig. 2 Schematic of parchment production

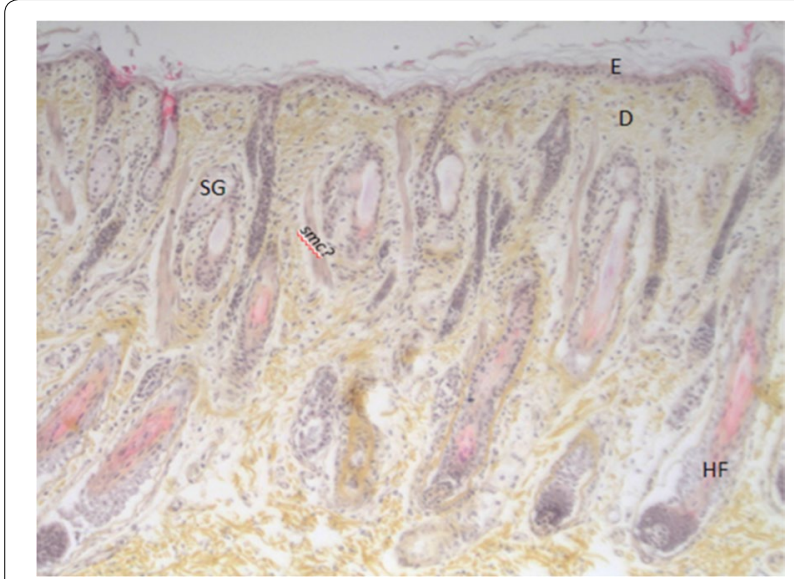

Fig. 3 Section of sample from fresh skin (Fig. 1) stained with HES (×100) (E, epidermis; D, dermis; SG, sebaceous Gland; HF = Hair Follicle; smc? = smooth muscle cells suspected)

\section{Dehaired skins}

The second samples were taken from the skin after light liming and hair removal (Fig. 4). It is known that after soaking in lime $\left(\mathrm{Ca}(\mathrm{OH})_{2}\right)$, the dermal fiber network in the skin expands [28]. We observed the loss of hairs, whose roots only persist here and there in the stratum

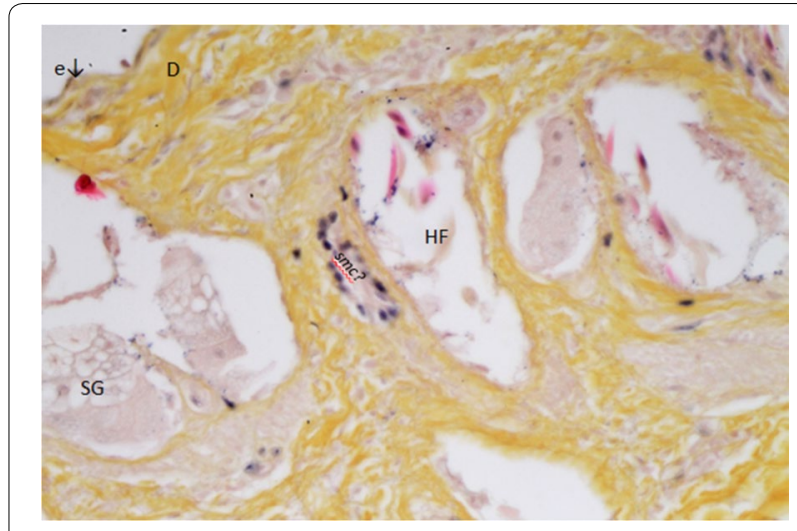

Fig. 4 Skin after hair removal, HES $(\times 400)(\mathrm{e} \downarrow$, rest of the epidermis; D, Dermis; SG, Sebaceous Gland; HF, Hair Follicle; smc, smooth muscle cells suspected)

basale of the epidermis (Fig. 4). All the stained components observed in the pre-treated skins were all still present after dehairing.

\section{Prolonged liming}

After the liming processes (three baths of increasing lime concentration; Fig. 5), collagen fibers seem now to have 


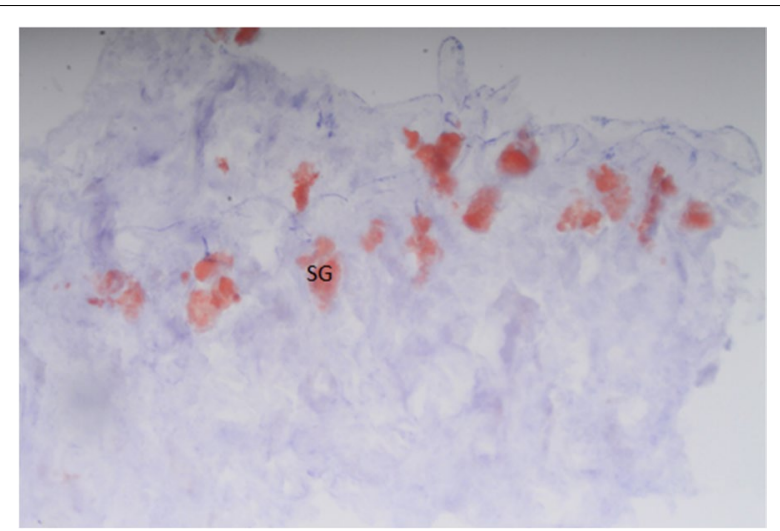

Fig. 5 ORO staining of skin after liming (×100) (SG, Sebaceous Gland)

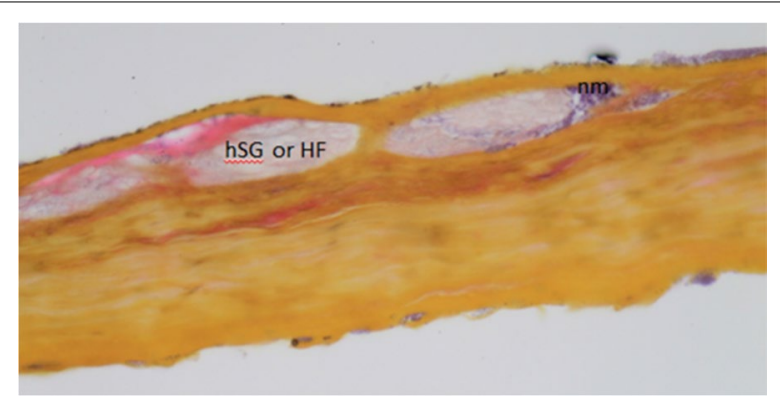

Fig. 6 HES staining of parchment taken out the frame $(\times 100)$ (hSG or $\mathrm{HF}$, horizontal Sebaceous Gland or Hair Follicle; nm, nuclear material

lost the characteristic fibrillar structure and appear to form a homogenous mass. Maxwell et al. [29] observed that "after salting there is an increase in the distance between the collagen molecules in the hydrated state, and even more expansion after liming, which is carried through the hierarchical levels up to fibril packing; deliming did not appear to reverse these increases, indicating that the effects of salting and liming are permanent". Elastin and reticulin fibers seem to be present only in traces. We observed that, despite remaining for three weeks in the lime solution, fat cells were still present, albeit most likely in a lower concentration (Fig. 5). The ability to remove fats from the skin is known to be related to duration in the lime bath (alkali causing saponification) and to the freshness (alkalinity) of the solution [30]; this aspect is worthy of further investigation.

\section{Final parchment}

The fourth samples were taken from the fully processed skin, i.e. the final parchment. During this final manufacturing step, the skin was put on a frame, scraped, bleached, cleaned and polished under tension (Fig. 6).
In the parchment samples, the bulk of the material took the form of a two dimensionally structured layer of uniformly oriented fibrous material, as observed here in cross-section (Fig. 6). This is consistent with our previous observations of optical birefringence patterns induced near the edges of parchment when stretched on a wooden frame [19]. The rest of the glands and hair follicles tend to reorient horizontally, i.e. parallel to the surface, in the direction of strain. Somewhat surprisingly-despite the fact that skins were taken from young or born dead animals and the final parchment was very thin $<0.1 \mathrm{~mm}-$ the production process did not remove all the fat cells (i.e. saponify all of the lipid). Oil red O staining revealed residual lipid deposits on the hair side of the skin.

The major histological changes observed at the different stages of skin transformation are revealed by the result of the six methods applied on samples and summarized in Table 1.

\section{Persistence of lipids}

The problem of residual grease bedevilled parchment makers in the past. Saxl [14] writes that "Sheep parchments have often a high grease content in the grain layer". "Magister Bernardus" (Bodleian Library Oxford. Canonici Misc. 128) recipe for parchment production deals with the subject of the removal of grease with warm dusting powders of chalk or other calcium salts or of wood ashes which melted the grease and acted like a "dubbin"; penetration was brought about by compressing the parchment.

Saxl's analysis of parchment recipes revealed that "degreasing was extensively practised in Italy in the fourteenth and fifteenth centuries and in France", and the practice was still being used by Messrs. Russell of Hitchin using a mixture of wood ash and soda added to the stretched (sheep) parchment on the frame which was then heated in a warm stove.

From an optimal tissue preservation standpoint, it is assumed that high levels of lipid dripping from heated parchment initiates combustion of the membranes. Ghioni et al. [31] report variable, but in some cases, substantial levels of lipid in historical and modern parchment. We conducted species identification [15] on seven of the samples analysed by Ghioni et al. [31], and in support of Saxl confirmed that the two membranes with high levels of lipid were from sheep (Fig. 7).

The production of fine wool has resulted in the selection of breeds with larger numbers of secondary follicles, resulting in a greater density of sebaceous glands, and thus sebocytes in sheep when contrasted with goat- and calf-skin. Two side effects of the greater number of secondary follicles in sheep are the higher levels of residual lipid and the disruption in the dermal collagen network, 
Table 1 The major histological changes observed at the different stages of skin transformation

\begin{tabular}{|c|c|c|c|c|c|c|}
\hline $\begin{array}{l}\text { Histological } \\
\text { staining methods }\end{array}$ & HES & Green Trichrome & Orcein & Picro-Sirius red & Wilder & Oil Red O \\
\hline $\begin{array}{l}\text { Histological speci- } \\
\text { ficity }\end{array}$ & & & Elastin & Type I Collagen & Type III Collagen & Lipids \\
\hline $\begin{array}{l}\text { Sample \#1: fresh } \\
\text { skin }\end{array}$ & $\begin{array}{l}\text { Classical topogra- } \\
\text { phy }\end{array}$ & $\begin{array}{l}\text { Classical topog- } \\
\text { raphy }\end{array}$ & $\begin{array}{l}\text { More Present at the } \\
\text { limit dermis- } \\
\text { hypodermis and } \\
\text { just around hair } \\
\text { follicles }\end{array}$ & $\begin{array}{l}\text { Present everywhere } \\
\text { Highest density } \\
\text { just around hair } \\
\text { follicles }\end{array}$ & $\begin{array}{l}\text { Anchored in the } \\
\text { basement mem- } \\
\text { branes }\end{array}$ & $\begin{array}{l}\text { At the apex of } \\
\text { epidermis and } \\
\text { in the seba- } \\
\text { ceous glands }\end{array}$ \\
\hline $\begin{array}{l}\text { Sample \#2: skin } \\
\text { after hair removal } \\
\text { (1.Watery lime bath; } \\
\text { 2. Milky lime bath) }\end{array}$ & $\begin{array}{l}\text { Loss of epidermis, } \\
\text { hair follicles with- } \\
\text { out hairs Evidence } \\
\text { for expanded } \\
\text { network of col- } \\
\text { lagen, } \\
\text { Persistent nuclei }\end{array}$ & Like HES & $\begin{array}{l}\text { Persistent in the } \\
\text { described zones }\end{array}$ & $\begin{array}{l}\text { Evidence of } \\
\text { expanded net- } \\
\text { work of collagen }\end{array}$ & $\begin{array}{l}\text { Basement } \\
\text { membranes less } \\
\text { emphasized }\end{array}$ & $\begin{array}{l}\text { Persistent in seba- } \\
\text { ceous glands }\end{array}$ \\
\hline $\begin{array}{l}\text { Sample } 3 \text { : skin after } \\
3 \text { lime baths }\end{array}$ & $\begin{array}{l}\text { Collagen gelled in a } \\
\text { kind of pulp }\end{array}$ & Like HES & Present in traces & $\begin{array}{l}\text { Collagen gelified } \\
\text { in pulp }\end{array}$ & Present in traces & $\begin{array}{l}\text { Persistent in seba- } \\
\text { ceous glands }\end{array}$ \\
\hline $\begin{array}{l}\text { Sample \#4: parch- } \\
\text { ment }\end{array}$ & $\begin{array}{l}\text { Layers in gelled } \\
\text { collagen Horizon- } \\
\text { talisation of the } \\
\text { glands }\end{array}$ & Like HES & $\begin{array}{l}\text { Present in parallel } \\
\text { traces }\end{array}$ & Quite uniform & $\begin{array}{l}\text { Present in parallel } \\
\text { traces or artefact? }\end{array}$ & $\begin{array}{l}\text { Persistent in seba- } \\
\text { ceous glands }\end{array}$ \\
\hline
\end{tabular}

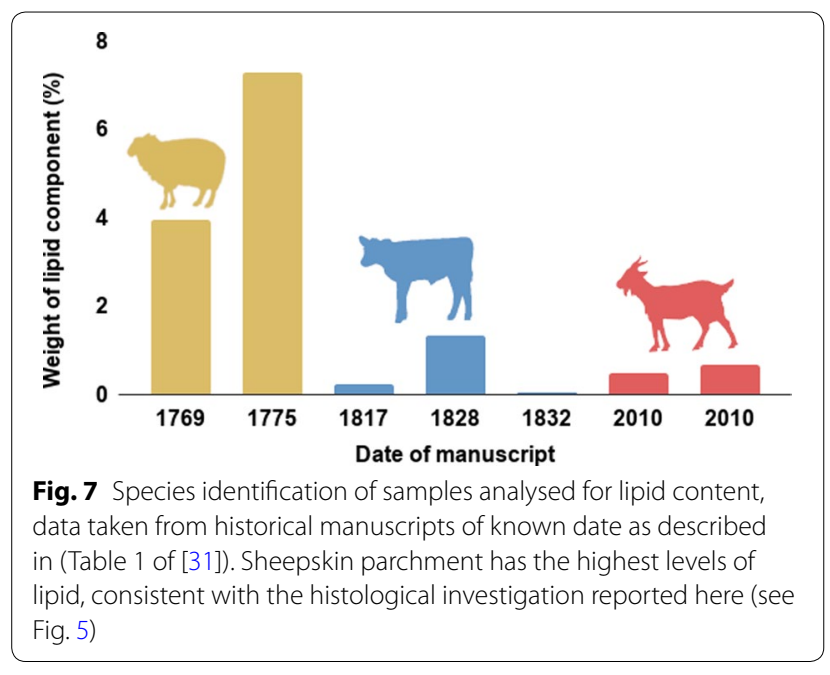

which means that there is a tendency for sheepskin to delaminate (that is for the parchment to split). Anecdotally, parchment maker Jessie Mayer (Pergamena, pers comm. 2015) concurs, and notes the difficulty of preparing parchment from wool sheep skins, due the excessive levels of lipid, which are not removed by the liming process.

\section{Conclusions}

Our histological study shows the modification of the biological material and more specifically the collagen fibrous material in the course of a parchment manufacturing experiment starting from skins of immature sheep. In particular, the modification and, ultimately, the disappearance of collagen type III fibers was observed (using the Wilder staining method) in addition to a progressive loss of elastin fibers. Another interesting observation is the persistence of fats, despite the decrease in quantity of the material stained with oil red O (so most likely lipids) as well as the genetic material observed with hemalaun staining.

Whilst we were unable to demonstrate any histological differences caused by the alternative deharing methods, the manufacture of parchment itself was shown to induce dramatic histological changes from the fresh skin. The transformation involved a progressive evolution from a classical full and complex three dimensional framework of biological material to a lamellar structure essentially composed of co-aligned collagen fibers. The most dramatic changes happen during the processes of drying and stretching on a frame. During this phase the thickness of the skin reduces and the collagen fibrils realign in the direction of the applied force.

With the reported recreation of historical parchment manufacture and tracking of skin transformation through histological analysis, we believe this study will help compensate for the lack of sources on microscopic changes in parchment during manufacture.

\section{Supplementary information}

Supplementary information accompanies this paper at https://doi. org/10.1186/s40494-020-00421-z.

Additional file 1. Table summarizing the details of histological analysis of sample "Still born lamb 1". 


\begin{abstract}
Acknowledgements
The authors would like to thank Nathalie Kirschvink from the Integrated research veterinary unit (URVI) from the University of Namur for providing domestic sheep skins from animals that died a natural death. Matthew Collins and Sarah Fiddyment acknowledge funding from Beasts to Craft (ERC Horizon 2020 Grant Agreement No. 787282). We thank Craig Kennedy for provision of the parchment samples from the earlier study C Ghioni, JC Hiller, CJ Kennedy, AE Aliev, M Odlyha, M Boulton, TJ Wess Journal of lipid research 46 (12), 2726-2734.
\end{abstract}

\section{Authors' contributions}

MF: experimental design, manufacture of parchment and writing. DVV: histological processing and interpretation of histological results. MC and SF Analysis of ancillary data. Figure preparations. CC, MC, SF, YP and OD: writing and interpretation of histological results. All authors read and approved the final manuscript.

\section{Funding}

This work was performed with the support of the Pergamenum21 project in the frame of the transdisciplinary research impulsion program of the University of Namur (NATRIP). MJC acknowledges support from the Danish National Research Foundation (178) and the ERC (Beasts to Craft; Horizon 2020 Grant Agreement No. 787282)

\section{Competing interests}

The authors declare that they have no competing interests.

\section{Author details}

${ }^{1}$ GSK Vaccines, Rue de I'Institut 89, 1330 Rixensart, Belgium. ${ }^{2}$ Department of Medicine, University of Namur, Rue de Bruxelles 61, 5000 Namur, Belgium. ${ }^{3}$ Department of Archaeology, The McDonald Institute, University of Cambridge, Downing St, Cambridge CB2 3ER, UK. ${ }^{4}$ Evogenomics, The Globe Institute Department of Health Sciences, University of Copenhagen, Sølvgade 83, København K, Denmark. ${ }^{5}$ Department of Physics, University of Namur, Rue de Bruxelles 61, 5000 Namur, Belgium.

Received: 13 May 2020 Accepted: 20 July 2020

Published online: 07 August 2020

\section{References}

1. Knight KR, Lepore DA, Horne RS, Ritz M, Hurley JV, Kumta S, et al. Collagen content of uninjured skin and scar tissue in foetal and adult sheep. Int J Exp Pathol. 1993;74:583-91.

2. Gbolagunte GD, Hambolu JO, Akpavie SO, et al. Pathology and leather surface appearance of disease afflicted Nigerian small ruminant skins. AU JT. 2009:4:271-83.

3. Dempsey M. Hide, Skin and Leather defects: A guide to their microscopy. Palmerston North: New Zealand Leather and Shoe Research Association; 1984.

4. Oznurlu Y, Celik I, Sur E, Telatar T, Ozparlak H. Comparative Skin Histology of the White New Zealand and Angora Rabbits. J Anim Vet Adv. 2009;8:1694-701.

5. Aktaș A, Dağlıŏlu S, et al. Examination of structural features of skin in sheep breeds fetuses with histological methods. Kafkas Univ Vet Fak Derg. 2009;15:391-6.

6. Passman A, Dalton DC. Influence of Romney, Coopworth, and Perendale breeds on lambskin leather quality. N Zealand J Exp Agric. 1982;10:7-13.

7. Mobini B. Histological feature of the skin at different regions and in different ages of Lori-Bakhtiari sheep. Leban Sci J/J Sci Liban. 2015;16:89.

8. Edmonds R, Cooper S. The importance of elastin distribution and morphology in ovine leather. J Aqeic. 2012. https://orion.euetii.upc.es/3web/ catA3/journal/repo/2012N63N3/eng/01.pdf.

9. Reich G. Leather. Ullmann's Encyclopedia of Industrial Chemistry. New York: Wiley-VCH Verlag GmbH \& Co. KGaA; 2000.

10. Reed R. Ancient skins, parchments and leathers. New York: Seminar Press; 1972.

11. Larsen R. Improved Damage Assessment of Parchment, IDAP: micro and non-destructive analysis and diagnosis for proper storage and treatment.
Cultural heritage research: a Pan-European challenge. cyfronet.krakow.pl; 2003. http://www.cyfronet.krakow.pl/ ncbratas/pdf/full_larsen.pdf.

12. Haines BM. Parchment: the physical and chemical characteristics of parchment and the materials used in its conservation. New York: The Leather Conservation Centre; 1999.

13. Saxl H. Histology of Parchment. Tech Stud Field Fine Arts. 1939;8:3-9.

14. Saxl H. An investigation of the qualities, the methods of manufacture and the preservation of historic parchment and vellum with a view to identifying the animal species used : being a thesis presented to the University of Leeds, Department of Leather Industries. Leeds: University of Leeds; 1954.

15. Fiddyment S, Holsinger B, Ruzzier C, Devine A, Binois A, Albarella U, et al. Animal origin of 13 th-century uterine vellum revealed using noninvasive peptide fingerprinting. Proc Natl Acad Sci USA. 2015;112:15066-71.

16. Diderot D, D'Alembert J-BR. Encyclopédie, ou Dictionnaire raisonneé des sciences, des arts et des métiers, par une société de gens de lettres. Bd. 1765.

17. Ryder ML. Follicle arrangement in skin from wild sheep, primitive domestic sheep and in parchment. Nature. 1958;182:781-3.

18. Ryder ML. The histological examination of skin in the study of the domestication of sheep. Zeitschrift für Tierzüchtung und Züchtungsbiologie. New York: Wiley; 1962.

19. Vilde V, Fourneau M, Charles C, Van Vlaender D, Bouhy J, Poumay Y, et al. Use of Polarised Light Microscopy to Improve Conservation of Parchment. Stud Conserv. 2019;64:284-97.

20. Dolgin B, Bulatov $V$, Schechter I. Non-destructive assessment of parchment deterioration by optical methods. Anal Bioanal Chem. 2007:388:1885-96.

21. Manfredi M, Bearman G, France F, Shor P, Marengo E. Quantitative multispectral imaging for the detection of parchment ageing caused by light: a comparison with ATR-FTIR, GC-MS and TGA analyses. Int J Conserv Sci. 2015;6:85.

22. Rabin I, Schütz R, Kindzorra E, Schade U, Hahn O, Weinberg G, et al. Analysis of an antique alum tawed parchment. Rome: Joint Interim-Meeting of five ICOM-CC Working Groups; 2010. p. 1-11.

23. Burley RW, Speakman JB. The plasticity of wool: part ii: variation with type of follicle. Text Res J. 1953;23:702-10.

24. Desvergnes AC. Skin Against Paper: Identification of Historical Interleaving Materials in Indo-Iranian Manuscripts. The Book and Paper Group Annual. 2015;34. https://www.semanticscholar.org/paper/1a7bcdd070 ac777f4cbc2ca50f65a9257f6bcd08.

25. Jensen GF, Springborg P. Care and Conservation of Manuscripts 8: Proceedings of the Eighth International Seminar Held at the University of Copenhagen 16th-17th October 2003. Museum Tusculanum Press; 2005.

26. Porter C. The Materiality of the Blue Quran: A Physical and Technological Study1. The Aghlabids and their Neighbors. Brill; 2018. p. 573-86.

27. Beale J. An Arte of making Parchment Vellum Glew. R Soc. 1663. https ://collections.royalsociety.org/DServe.exe?dsqlni=Dserve.ini\&dsqAp $\mathrm{p}=$ Archive $\& d s q D b=$ Catalog $\& d s q C m d=$ show.tcl $\& d s q$ Search $=($ RefNo $==\% 27 \mathrm{MS} \% 2 \mathrm{~F} 215 \% 2 \mathrm{~F} 54 \% 27$ ).

28. Kennedy CJ, Wess TJ. The structure of collagen within parchment-a Review. Restaurator. 2003;24:61-80.

29. Maxwell CA, Wess TJ, Kennedy CJ. X-ray diffraction study into the effects of liming on the structure of collagen. Biomacromolecules. 2006;7:2321-6.

30. Gottscher L. Ancient methods of parchment-making: discussion on recipes and essays experimental. In: Maniaci M, Paola Munafò PF, editors. Ancient and Medieval Book Materials and Techniques (Erice, 18-25 September 1992). Vatican City: Biblioteca Apostolica Vaticana; 1993. p. 1-56.

31. Ghioni C, Hiller JC, Kennedy CJ, Aliev AE, Odlyha M, Boulton M, et al. Evidence of a distinct lipid fraction in historical parchments: a potential role in degradation? J Lipid Res. 2005;46:2726-34.

\section{Publisher's Note}

Springer Nature remains neutral with regard to jurisdictional claims in published maps and institutional affiliations. 